\title{
Prospects for Regeneration Solid Tooth Tissues by Synthesis of Biocompatible Hydroxyapatite in Reactions with Non-Toxic Components
}

\author{
Akhmetshin ED* and Vorobyova YD \\ Department of Chemistry and Technology of Crystals, Russia
}

*Corresponding author: Akhmetshin ED, Department of Chemistry and Technology of Crystals, Russia, D.Mendeleev University of Chemical Technology of Russia

\section{ARTICLE INFO}

Received: 幽 November 13, 2019

Published: 慧 November 19, 2019

Citation: Akhmetshin ED, Vorobyova YD. Prospects for Regeneration Solid Tooth Tissues by Synthesis of Biocompatible Hydroxyapatite in Reactions with NonToxic Components. Biomed J Sci \& Tech Res 23(1)-2019. BJSTR. MS.ID.003842.

Keywords: Akhmetshin ED, Department of Chemistry and Technology of Crystals, Russia, D.Mendeleev University of Chemical Technology of Russia

\section{ABSTRACT}

Currently, there is no technology for the regeneration of hard tooth tissues directly in the oral cavity, despite the success in the synthesis of hydroxyapatite. First of all, this is due to the use of toxic components in the synthesis. Thus, the development of a technology for producing hydroxyapatite in metabolic reactions with non-toxic components is very important, since in the future it allows you to create methods for the regeneration of damaged areas in the hard tissues of the tooth directly in the oral cavity. This publication presents the chemical reactions we have developed for the synthesis of hydroxyapatite, carried out under conditions close to the conditions of oral homeostasis using non-toxic starting components in systems: $\mathrm{CaCO}_{3}-\mathrm{Na}_{2} \mathrm{HPO}_{4}{ }^{*} 12 \mathrm{H}_{2} \mathrm{O} ; \mathrm{Ca}\left(\mathrm{HCO}_{3}\right)_{2}-$ $\mathrm{Na}_{2} \mathrm{HPO}_{4}{ }^{*} 12 \mathrm{H}_{2} \mathrm{O} ; \mathrm{Ca}\left(\mathrm{HCO}_{3}\right)_{2}+\mathrm{CaCO}_{3}-\mathrm{Na}_{2} \mathrm{HPO}_{4}{ }^{*} 12 \mathrm{H}_{2} \mathrm{O} ; \mathrm{Ca}\left(\mathrm{HCO}_{3}\right)_{2}-\mathrm{NaH}_{2} \mathrm{PO}_{4}{ }^{*} 2 \mathrm{H}_{2} \mathrm{O}$. As a result, hydroxyapatite was obtained in the form of crystals of various morphology. In some of the proposed reactions, the yield of hydroxyapatite was $100 \%$. The result allows us to further develop a technology for the regeneration of bone tissues and hard tissues of the tooth directly in a living organism.

\section{Short Communication}

The normal vital activity of the whole organism is due to the constant regeneration of the cellular composition, which improves the condition of whole tissues and organs. There are different systems of tissues, and most importantly - the temporary limit of self-healing. Some tissues are updated from the moment of birth to death, while others - to a certain age [1,2]. Due to the fact that the body cannot always "heal" itself, the development of technologies and the replenishment of knowledge about various materials gave rise to such a direction as the science of biomaterials. The function of biomaterials is to replace a damaged area of tissue or an entire organ. The main requirement for such materials is their biocompatibility. This is the ability of materials to perform their functions and not cause rejection processes in the body. Unfortunately, they cannot ensure full functioning for life and require expensive replacement, and there is also a risk of an unpredictable reaction of the body to materials of exogenous origin, although biocompatible but not bioidentical, during implantation. Bioidentity is a property of materials that have the same chemical compositions and chemical structure as materials of endogenous origin. The development of the technology for producing bio-identical materials directly in a living organism will allow the regeneration process in bone and dental tissues and replace expensive implants with bio-identical material $[3,4]$. There is an important similarity in the structure of tooth and bone tissue. Both teeth and bones contain hydroxyapatite crystals $\left(\mathrm{Ca}_{10}\left(\mathrm{PO}_{4}\right)_{6}(\mathrm{OH})_{2}\right.$ - basic calcium phosphate with a ratio of $\mathrm{Ca} / \mathrm{P}=1.67$ ) in their structure.

In tooth tissue up to $97 \%$, and in bone mass up to $60 \%$. Together with other inorganic compounds, a small amount of water (about $3 \%$ of the total mass) and proteins of the two classes, the hexagonal prisms of hydroxyapatite crystals are folded into a dense bio composite material. It is not yet possible to completely reproduce its properties in artificial materials. None of the known methods for 
producing hydroxyapatite is suitable for the regeneration of dental tissue in the oral cavity and bone tissue directly at the site of damage. Due to the fact that all the methods studied involve obtaining hydroxyapatite under specific conditions and further implanting in one form or another on areas of bone or dental tissue, most often - applying hydroxyapatite to implants made of various metals, ceramics, alloys in order to make these materials biocompatible [57]. In attempts to synthesize hydroxyapatite close to endogenous origin, a material similar in composition to hydroxyapatite was obtained, this brushite is $\mathrm{CaHPO}_{4} \cdot 2 \mathrm{H}_{2} \mathrm{O}$, however, it is significantly inferior to hydroxypatite in terms of hardness (in brushite 2.5) and the solubility of brushite is much higher (in hydroxyapatite $0.003 \mathrm{~g} / 100 \mathrm{ml}$ ), which also makes it impossible to use it as a regenerating compound [8]. An alternative is the synthesis of biocompatible hydroxyapatite with a hardness of 5 on the Mohs scale and a solubility of $0.0003 \mathrm{~g} / \mathrm{l}$. Previously, reactions have been carried out to obtain biocompatible hydroxyapatite in the laboratory using non-toxic components $[9,10]$. Which already allows us to positively assess the prospects of such processes for subsequent use in order to regenerate dental and bone tissues.

\section{Experimental Part}

To obtain biocompatible hydroxyapatite in exchange reactions with non-toxic components, calcium carbonate powder was chosen as a donor $\mathrm{CaCO}_{3}$, solution $\mathrm{Ca}\left(\mathrm{HCO}_{3}\right)_{2}$ and mixture $\mathrm{CaCO}_{3}$ + Ca $\left(\mathrm{HCO}_{3}\right)_{2}$; sodium phosphate was a phosphate group donor $\mathrm{Na}_{2} \mathrm{HPO}_{4}{ }^{*} 12 \mathrm{H}_{2} \mathrm{O}$ and $\mathrm{NaH}_{2} \mathrm{PO}_{4}{ }^{*} 2 \mathrm{H}_{2} \mathrm{O}$. The reactions were carried out under conditions close to the conditions of oral homeostasis, namely at a temperature of $26-29^{\circ} \mathrm{C}$, at a pressure of 1 atmosphere using non-toxic starting components.

For conducting ion-exchange reactions, two main methods were chosen:

a) Interaction of solutions of disubstituted sodium phosphates with a solution of calcium carbonate;

b) Interaction of solutions of disubstituted sodium phosphates with a solution of calcium bicarbonate in various stoichiometric ratios.
All reactions performed were divided into series depending on the selected calcium donors and phosphate groups. Within the series, the experiments differed in the ratio of the starting components.

\section{Current reactions}

Series 1: Hydroxyapatite synthesis in system: $\mathrm{Na}_{2} \mathrm{HPO}_{4}{ }^{*} 12 \mathrm{H}_{2} \mathrm{O}$ $-\mathrm{CaCO}_{3}$

Series 2: Hydroxyapatite synthesis in system: $\mathrm{NaH}_{2} \mathrm{PO}_{4}{ }^{*} 2 \mathrm{H}_{2} \mathrm{O}$ $-\mathrm{CaCO}_{3}$

Series 3: Hydroxyapatite synthesis in system: $\mathrm{Na}_{2} \mathrm{HPO}_{4}{ }^{*} 12 \mathrm{H}_{2} \mathrm{O}$ $-\mathrm{Ca}\left(\mathrm{HCO}_{3}\right)_{2}$

Series 4: Hydroxyapatite synthesis in system: $\mathrm{Na}_{2} \mathrm{HPO}_{4}{ }^{*} 12 \mathrm{H}_{2} \mathrm{O}$ $-\mathrm{Ca}\left(\mathrm{HCO}_{3}\right)_{2}+\mathrm{CaCO}_{3}$

The concentration of the prepared solutions was calculated taking into account the alternating excess of one of the starting components to identify patterns between the highest yield and the optimal ratio. The solutions were precipitated in a centrifuge to speed up the process of preparing samples for research. Precipitation was dried in air without heating [11-13].

The main characteristics of the experiments:

a) The pH of the solutions was in the range from 5.8 to 9.7

b) The ratio of the starting components: $1: 1,1: 2,1: 3,2: 1$, 3: 1 in separate experiments 16: 1 .

After drying, the obtained samples were further studied by various methods, namely, the crystal-optical method and scanning electron microscopy method for studying the morphology of crystals and using the method of x-ray phase analysis to study the phase composition of the obtained samples.

\section{Experimental Results}

The obtained experimental results were summarized in the table, below are the individual series with the highest yield of the target product (Table 1).

Table 1: Examples of experimental results and research of precipitation obtained by $\mathrm{X}$-ray phase.

\begin{tabular}{|c|c|c|c|c|c|}
\hline \multirow{2}{*}{ № } & \multirow{2}{*}{ № sample } & \multirow{2}{*}{$\begin{array}{l}\text { Ratio } \\
\text { P/Ca }\end{array}$} & \multirow{2}{*}{$\begin{array}{c}\text { Precipitation phase composition determined } \\
\text { by the method X-ray phase } \\
\text { The presence } \mathrm{CaCO}_{3}\end{array}$} & \multirow[b]{2}{*}{$\begin{array}{l}\text { The presence of sodi- } \\
\text { um phosphate }\end{array}$} & \multirow[b]{2}{*}{$\begin{array}{c}\text { The presence of hydroxyapa- } \\
\text { tite } \mathrm{Ca}_{5}\left(\mathrm{PO}_{4}\right)_{3}(\mathrm{OH})\end{array}$} \\
\hline & & & & & \\
\hline \multicolumn{6}{|c|}{ Series 2. Hydroxyapatite synthesis in system: $\mathrm{NaH}_{2} \mathrm{PO}_{4}{ }^{*} 2 \mathrm{H}_{2} \mathrm{O}-\mathrm{CaCO}_{3}$} \\
\hline 1 & 2.1 & 1:01 & $\begin{array}{c}+ \\
23,3 \%\end{array}$ & - & $\begin{array}{c}+ \\
76,7 \% \\
\end{array}$ \\
\hline 2 & 2.2 & 2:01 & $\begin{array}{c}+ \\
29,9 \% \\
\end{array}$ & - & $\begin{array}{c}+ \\
70,1 \% \\
\end{array}$ \\
\hline \multicolumn{6}{|c|}{ Series 3. Hydroxyapatite synthesis in system: $\mathrm{Na}_{2} \mathrm{HPO}_{4}{ }^{*} 12 \mathrm{H}_{2} \mathrm{O}-\mathrm{Ca}\left(\mathrm{HCO}_{3}\right)_{2}$} \\
\hline 3 & 3.2 & 2:01 & $\begin{array}{c}+ \\
52,9\end{array}$ & - & $\begin{array}{c}+ \\
40,1 \%\end{array}$ \\
\hline
\end{tabular}




\begin{tabular}{|c|c|c|c|c|c|}
\hline 4 & 3.3 & $3: 01$ & - & - & + \\
\hline 5 & 3.4 & $8: 01$ & - & - & $100 \%$ \\
\hline
\end{tabular}

\section{Research and Analysis of The Results Obtained}

To analyze the obtained samples, we used the crystal optical research method, scanning electron microscopy and the method of X-ray phase analysis. Samples were studied by X-ray powder diffractometry using an EQUINOX $2000 \mathrm{X}$-ray diffractometer (INEL Inc., France) using copper radiation $(\mathrm{K} \alpha 1=1.54056 \AA ీ)$ in steps of 0.03 degrees. Processing of the obtained $x$-ray was performed using the Match2! Software part. Below is the diffraction pattern of sample №. 3.3 in the system $\mathrm{Na}_{2} \mathrm{HPO}_{4}{ }^{*} 12 \mathrm{H}_{2} \mathrm{O}-\mathrm{Ca}\left(\mathrm{HCO}_{3}\right)_{2}$ with a ratio of the starting components of $3: 1$, which shows the peaks corresponding to the hydroxyapatite phase. (Figures 1) By the method of non- destructive testing of XRD, 34 samples were researched, of which in the 21 samples the presence of hydroxyapatite in an amount of from $8.7 \%$ to $100 \%$ was recorded. The percentage is the result of an automatic calculation. Some samples were selected for further crystal-optical studies of crystal morphology using the MIN8 mineralogical immersion microscope and the Tescan Vega3 scanning electron microscope. Below are the results of scanning electron microscopy for individual series: On (Figures 2 \& 3) differently oriented needle-shaped crystals are visible, which in their morphology are like hydroxyapatite crystals located in tooth enamel (Figures $3 \& 4$ ).

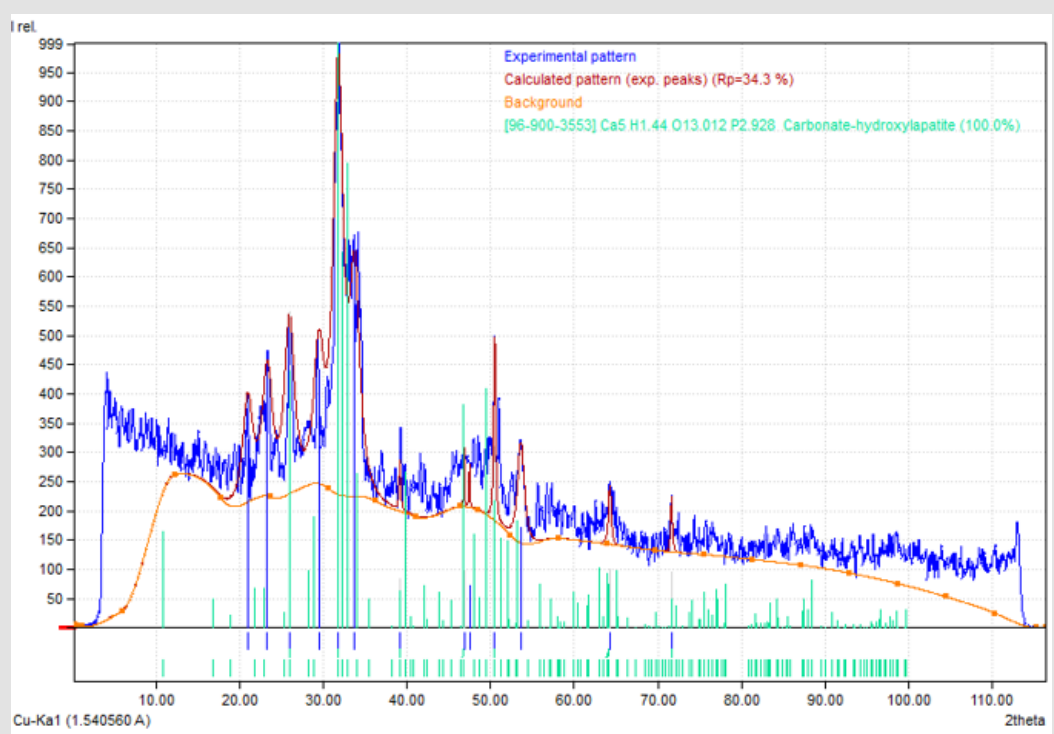

Figure 1: Diffraction pattern of sample No. 3.3.
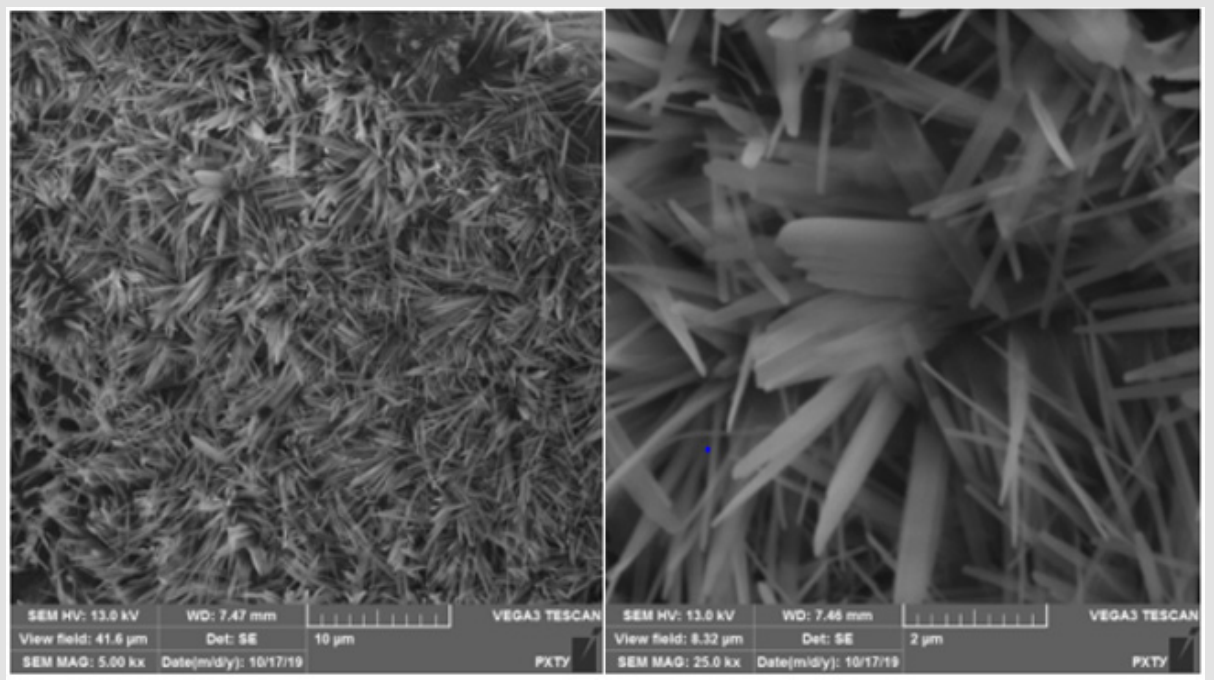

Figure 2,3: The obtained SEM image of needle crystals of hydroxyapatite of sample 2.2. 


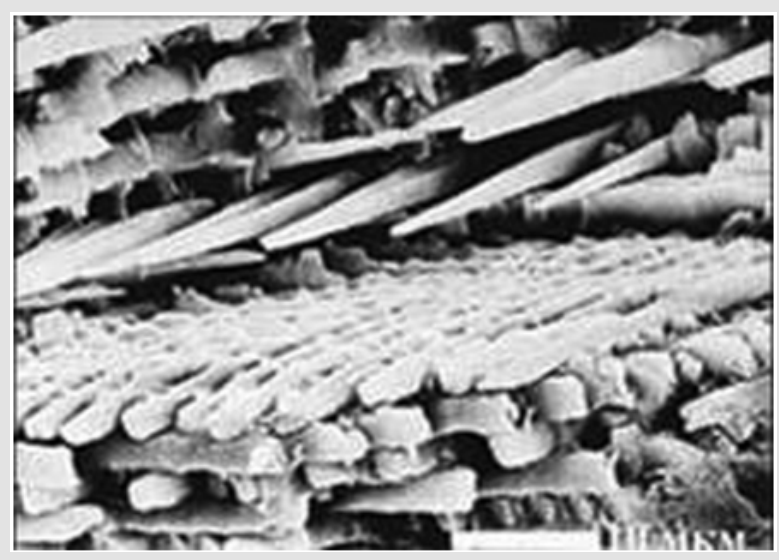

Figure 4:SEMimage of "needle" crystals of microcrystalline HAP enamel, (X 20,000, JSM-6380LV, JEOL) [11,12].

It is also possible to observe tabular-shaped hydroxyapatite crystals (Figures 5 \& 6), which may indicate a different crystallization rate. It should be noted that depending on the topography and degree of maturity of the enamel, the shape and size of hydroxyapatite crystals in it will also be different. Thus, our work shows the possibility of obtaining a 100\% yield for individual reactions of the most important biocompatible material hydroxyapatite in metabolic reactions with non-toxic components. The main factors affecting the yield of hydroxyapatite are the use of a solution of calcium hydrogen carbonate as a calcium donor and the P / Ca ratio with a significant excess of sodium, namely in the system $\mathrm{Na}_{2} \mathrm{HPO}_{4}{ }^{*} 12 \mathrm{H}_{2} \mathrm{O}-\mathrm{Ca}\left(\mathrm{HCO}_{3}\right)_{2}$ with a ratio of 8: 1 or more the maximum yield of hydroxyapatite was observed and was $100 \%$. These results may open up prospects for the technology of regeneration in hard tissues of the tooth by conducting synthesis directly in the oral cavity.

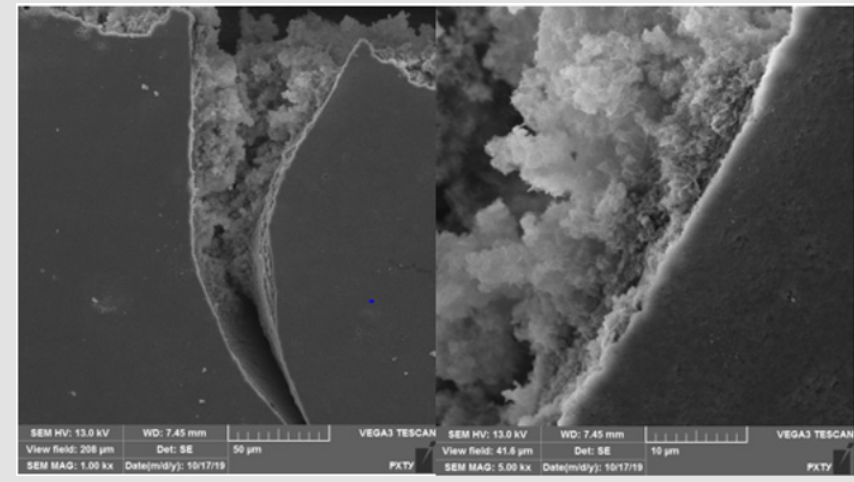

Figure 5,6: The obtained SEM image of the hydroxyapatite crystals of the tabular structure of sample 3.3.

\section{Conclusion}

a) Synthesis of hydroxyapatite under conditions of homeostasis $\left(\mathrm{t}=24-28^{\circ} \mathrm{C}, \mathrm{p}=1\right.$ атм) in system: $\mathrm{CaCO}_{3}-$
$\mathrm{Na}_{2} \mathrm{HPO}_{4}{ }^{*} 12 \mathrm{H}_{2} \mathrm{O}$; $\mathrm{Ca}\left(\mathrm{HCO}_{3}\right)_{2}-\mathrm{Na}_{2} \mathrm{HPO}_{4}{ }^{*} 12 \mathrm{H}_{2} \mathrm{O}$; $\mathrm{Ca}\left(\mathrm{HCO}_{3}\right)_{2}+\mathrm{CaCO}_{3}-$ $\mathrm{Na}_{2} \mathrm{HPO}_{4}{ }^{*} 12 \mathrm{H}_{2} \mathrm{O}$; $\mathrm{Ca}\left(\mathrm{HCO}_{3}\right)_{2}-\mathrm{NaH}_{2} \mathrm{PO}_{4}{ }^{*} 2 \mathrm{H}_{2} \mathrm{O}$ is possible. The best results are obtained in systems: $\mathrm{CaCO}_{3}-\mathrm{NaH}_{2} \mathrm{PO}_{4}{ }^{*} 2 \mathrm{H}_{2} \mathrm{O}$ and $\mathrm{Ca}$ $\left(\mathrm{HCO}_{3}\right)_{2}-\mathrm{NaH}_{2} \mathrm{PO}_{4} * 2 \mathrm{H}_{2} \mathrm{O}$. In these series, the yield of hydroxyapatite was maximum and reached $100 \%$ in some experiments.

b) As a result of studying the morphology of the crystals of the obtained biocompatible hydroxyapatite, the formation of various forms of crystals was revealed: needle-shaped, tabular. This may indicate a different crystallization rate.

The results of this research work can be used to develop a technology for repairing damaged areas of tooth hard tissues by conducting hydroxyapatite synthesis directly in the oral cavity due to the use of non-toxic components, ease of synthesis and good reproducibility of the results.

\section{References}

1. The journal Science and Life. The Third Way-Regeneration.

2. L Polezhaev. Doctor of Biological Sciences. (Institute of Development Biology, USSR Academy of Sciences).

3. Baderddinov RR. The scientific journal Successes of modern science.

4. Sharkeev Yu P. Basis of interaction of biological tissues with artificial materials. The subject of medical materials science. The concept of implants.

5. Sharkeev Yu P. basis of interaction of biological tissues with artificial materials. The main classes of materials for medicine, medical equipment and dentistry.

6. Kuleshov KS. Obtaining synthetic hydroxyapatite for the formation of biocoatings on medical implants.

7. Kunenkov EV (2009) Synthesis of nanocrystalline calcium hydroxyapatite from calcium sugars and ammonium hydrogen.

8. Safronova TV (2007) Hydroxyapatite-based ceramic materials obtained from solutions of various concentrations. Inorganic materials 43(8): 901-909.

9. Putlyaev Valery Ivanovich (RU), Lukin Evgeny Stepanovich (RU), Tretyakov Yuri Dmitrievich (RU), Reshotka Daria Sergeevna (RU), Safronova Tatyana Viktorovna (RU) patent 2431599.

10. Akhmetshin EA, Zhibarev AM. RF patent No. 2505479.

11. Akhmetshin EA, Zhibarev AM (2014) Proceedings of the Academy of Sciences: Chemical Series 5. Prospects for producing bioidentical materials.

12. Kashkarov VM, Goloshchapov DL, Domashevskaya EP, Shumilovich BR (2011) XRF and IF studies of nanocrystalline synthesized and biogenic HAP. Surface. X-ray synchrotron and neutron studies 12: 1-7.

13. Kunin AA (2008) Topological features of the mineral and organic components of tooth enamel. Voronezh: Bulletin of the Institute of Dentistry 6: 4-6. 


\section{ISSN: 2574-1241}

DOI: 10.26717/BJSTR.2019.23.003842

Akhmetshin ED. Biomed J Sci \& Tech Res

(C) (P) This work is licensed under Creative

Submission Link: https://biomedres.us/submit-manuscript.php

$\begin{array}{ll}\text { BIOMEDICAL } & \text { Assets of Publishing with us } \\ \text { RESEARCHES } & \text { Global archiving of articles } \\ \text { - Immediate, unrestricted online access }\end{array}$

